\title{
Pengembangan Wisata Berbasis Masyarakat Untuk Meningkatkan Perekonomian Masyarakat Desa Sekapuk Kecamatan Ujung Pangkah Kabupaten Gresik
}

\author{
Nasirudin Al Ahsani' ${ }^{1}$, Kharisma Fitrotul $\mathbf{H}^{2}$, \\ Ana Fauziyah $\mathbf{I}^{3}$, Berliantin Nahdiya $\mathbf{I}^{4}$ \\ Universitas Islam Negeri Kiai Haji Achmad Shiddiq Jember \\ nasirudin@iain-jember.ac.id
}

\begin{abstract}
The water quality of the rivers in Gresik, specifically in Bengawan Solo river in Bungah-Ujung Pangkah area and the downstream of Brantas River in the Wringinanom-Driyorejo Region, is polluted as perceived from the total dissolved solids that reaches 5000 ppm. Meanwhile, the river water contaminated with microplastics in Bengawan Solo reaches 55.2/100 L and the downstream of Brantas River reaches $18.5 / 100$ L3. The garbage does not only accumulate in rivers, but also on land. In Sekapuk Village, Ujung Pangkah Subdistrict, Gresik, there is a former limestone mine. Since the mining was completed, it ended up being a landfill from 2003 through 2017. The current study employs a qualitative research method. The data were collected from interviews, observation, and documentation. The objectives of this study are: 1) To determine the components of tourism and participatory planning in Setigi tourist attraction, 2) To determine the community development and empowerment in Setigi tourist attraction, and 3) to determine the supporting and inhibiting factors in managing Setigi tourist attraction. The results of this study are as follows: 1) Setigi tourist attraction's components include parking areas, toilets, prayer rooms, gazebos, photo spots, culinary areas, ATV cars, and others. The planning of this tourist attraction came from an idea of the village head to make the village into a tourist attraction. As a result, a regular meeting is held on the 1st of every month which is attended by members of BUMDES, PEMDES, other village institutions such as local community units (RT \& RW) and other community members, 2) The community development is carried out by providing opportunities to establish stalls for women in family welfare program (PKK) groups and each local community unit (RT /RW) in Sekapuk Village, 3) The supporting factors are the ability and the willingness to establish Setigi tourist attraction. Meanwhile, the inhibiting factor is the limited funds in the tourist attraction development, but a joint saving program was planned by the village head.
\end{abstract}

Keywords: Community Based Tourism Development, Waste Management, Setigi Tourist Attraction. 


\section{Abstrak}

Kualitas air sungai di Kaputen Gresik, tepatnya di Bengawan Solo wilayah BungahUjung pangkah dan Kali Brantas Hilir Wilayah Wringinanom-Driyorejo tercemar karena tingginya total dissolved solid yang mencapai 5000 ppm. Sedangkan air sungai yang terkontaminasi Mikroplastik di Bengawan Solo 55,2/ 100 L dan kali Brantas Hilir 18,5/ 100 L 3. Sampah tidak hanya menumpuk di sungai, tatapi juga di daratan. Di Desa Sekapuk Kecamatan Ujung Pangkah Kabupaten Gresik terdapat bekas tambang kapur. Karena penambangan sudah selesai, akhirnya menjadi tempat pembuangan sampah dari 2003-2017. Penelitian ini dengan menggunakan metode penelitian kualitatif. Teknik pengambilan data dengan wawancara, observasi, dan dokumentasi. Tujuan dari penelitian ini adalah: 1) Untuk mengetahui komponen wisata dan perencanaan partisipatif pada wisata Setigi, 2) Untuk mengetahui pengembangan dan pemberdayaan masyarakat pada wisata Setigi, dan 3) untuk mengetahui faktor pendorong dan penghambat dalam mengelola wisata Setigi. Hasil dari penelitian ini: 1) Komponen wisata Setigi adalah Parkir, Toilet, Mushola, Gazebo, Spot Foto, Area kuliner, mobil ATV, dan lainnya. Perencanaan wisata ini dimulai dari ide dari kepala desa untuk menjadikannya tempat wisata. Sehingga dilakukan pertemuan rutin setiap bulan di tanggal 1 yang di hadiri oleh para anggota BUMDES, PEMDES, lembaga desa lainya seperti (RT \& RW) dan anggota masyarakat lainnya, 2) Pengembangan masyarakat dengan cara memberikan kesempatan membuka stand bagi kelompok ibu PKK dan tiap RT/RW yang ada di Desa Sekapuk, 3) Faktor pendukung adalah kemampuan dan kemauan dalam menjalankan wisata setigi ini. Sedangkan faktor penghambat adalah keterbatasan dana dalam pembangunan wisata, namun kepala desa memiliki ide dengan cara program menabung bersama.

Kata Kunci: Pengembangan Wisata Berbasis Wisata, Pengelolaan Sampah, Wisata Setigi.

\section{Pendahuluan}

Sampah atau waste dalam Bahasa Inggris merupakan suatu bahan yang dibuang atau terbuang dari aktivitas manusia. Sampah merupakan bentuk konsekuensi dari adanya aktivitas manusia. Secara sederhana sampah terbagi menjadi 2, yaitu organik dan anorganik. Organik adalah sampah basah yang berasal dari makhluk hidup, seperti dedaunan dan sampah dapur. Sedangkan sampah anorganik adalah sampah yang tidak dapat terurai, seperti kaleng, karet, logam, plastik yang merupakan sampah kering. ${ }^{1}$

Pada abad ke-17 penduduk Belanda masih banyak yang membuang sampah di mana-mana sehingga menimbulkan banyak penyakit. Maka pemerintah setempat menyediakan tempat untuk pembuangan sampah. Lalu pada abad ke-19, sampah masih tetap dikumpulkan di tempat tertentu, tetapi bukan lagi penduduk yang membuang, melainkan petugas yang diangkat oleh pemerintah yang mengambil dari rumah penduduk. Mulai abad ke-20 sampah tidak ditimbun, melainkan dibakar. Kondisi sampah di Negeri Belanda saat itu kira-kira sama dengan

\footnotetext{
${ }^{1}$ Tim Penulis PS, Penanganan dan Pengolahan Sampah (Bogor: Penebar Swadaya, 2008), 3-6.
} 
Indonesia saat ini. Akhirnya pada abad ke-21 sampah masih dibakar tetapi dengan teknologi pembakaran sampah sehingga gas beracun tidak membahayakan kesehatan masyarakat, justru dapat menguntungkan masyarakat karena menjadi pembangkit listrik. ${ }^{2}$ Demikian kondisi sampah di Negeri Belanda.

Sedangkan di Indonesia sampah masih menjadi problem yang tak kunjung selesai. Kementerian Lingkungan Hidup dan Kehutanan menyebutkan sampah dari 289 kabupaten se-Indonesia pada tahun 2020 mencapai 36.725.828,83 ton pertahun. Dari 3 juta ton tersebut, hanya 53,79\% yang terkelola. Sedangkan 46,21\% sisanya tidak terkelola dengan baik. ${ }^{3}$ Dari data tersebut dapat kita pahami, masalah sampah khususnya di Indonesia masih menjadi pekerjaan rumah yang belum terselesaikan. Maka butuh kontribusi para ilmuan, pemerintah dan masyarakat untuk menyelesaikan hal tersebut.

Di Kabupaten Jember, Ziadatur Rizkiyah, Ketua TCC (Trash Control Community) mengaku telah melakukan penelitian terhadap kualitas air Sungai di wilayah Gresik Utara dan Selatan. Lokasi penelitian di Gresik Utara terletak pada Bengawan Solo wilayah Bungah-Ujung pangkah, sedangkan Gresik Selatan di Kali Brantas Hilir Wilayah Wringinanom-Driyorejo. Hasil penelitian menunjukkan kualitas air di sungai tersebut tercemar karena tingginya total dissolved solid yang mencapai 5000 ppm. Sedangkan air sungai yang terkontaminasi Mikroplastik di Bengawan Solo 55,2/ 100 L dan kali Brantas Hilir 18,5/ 100 L 3. ${ }^{4}$ Berikut adalah kondisi sampah yang ada di sungai sekitar Gresik.

Ternyata pencemaran akibat sampah tidak hanya di sungai saja, tetapi juga di daratan. Di Desa Sekapuk Kecamatan Ujung Pangkah Kabupaten Gresik terdapat bekas tambang kapur. Karena penambangan sudah tidak dilakukan, akhirnya lokasi tersebut dijadikan tempat pembuangan sampah oleh warga sekitar dari tahun 2003 hingga 2017. Hal tersebut menjadikan lingkungan tercemar. Menurut penuturan Abdul Halim, Kepala Desa Sekapuk dulu ketebalan sampah mencapai 12 hingga 14 meter. Tinggi dan besar sekali. Apalagi jika musim hujan tiba, sampah-sampah tersebut akan mengeluarkan bau busuk. ${ }^{5}$

Dari bekas tambang hingga menjadi sampah yang menumpuk bertahuntahun, mampu disulap menjadi sebuah tempat wisata yang ramah lingkungan serta

\footnotetext{
2 Nurwita Utami, "Pengelolaan Sampah Di Negara-Negara Maju," Indonesia Environment \& Energy Center (blog), 8 Juni 2020, https://environment-indonesia.com/pengelolaan-sampah-dinegara-negara-maju/.

3 "SIPSN - Sistem Informasi Pengelolaan Sampah Nasional," diakses 8 Juli 2021, https://sipsn.menlhk.go.id/sipsn/.

4 jatimnet.com dan jatimnet.com, "Bahaya Tumpukan Sampah Plastik di Gresik Mengancam," Bahaya Tumpukan Sampah Plastik di Gresik Mengancam, diakses 28 Juli 2021, https://jatimnet.com/bahaya-tumpukan-sampah-plastik-di-gresik-mengancam.

5 Ayo Media Network, "Setigi, Wisata Anyar Bekas Batu Kapur dan Tempat Pembuangan Sampah," AyoSurabaya.com, diakses 28 Juli 2021, https://www.ayosurabaya.com/read/2021/06/ 15/11964/setigi-wisata-anyar-bekas-batu-kapur-dan-tempat-pembuangan-sampah.
}

Nasirudin Al Ahsani, dkk | 141 
dapat meningkatkan perekonomian masyarakat. Bahkan desa ini pernah menyabet juara 1 desa brilian se-Indonesia dalam Program Inkubasi BRIncubator Goes to Desa Brilian. ${ }^{6}$

Berdasarkan permasalahan yang sudah dipaparkan sebelumnya, peneliti tertarik untuk mengangkat judul "pengembangan wisata berbasis masyarakat untuk meningkatkan perekonomian masyarakat Desa Sekapuk Kecamatan Ujung Pangkah Kabupaten Gresik" pada penelitian ini.

\section{Metode Penelitian}

Penelitian ini dengan menggunakan metode penelitian kualitatif. Teknik pengambilan data dengan wawancara, observasi, dan dokumentasi. Untuk mendapatkan data yang akurat maka penelitian ini juga menggunakan metode triangulasi sumber. Pembahasan dalam penelitian ini termasuk jenis penelitian deskriptif. Lokasi penelitiani ini di Jl. Raya Deandles No. 33-88 Desa Sekapuk Kecamatan Ujung Pangkah Kabupaten Gresik.

\section{Pembahasan}

\section{Profil Wisata Setigi}

Wisata Setigi bermula yang dulunya bekas tambang kapur dan di jadikan tempat pembuangan sampah warga sekitar dari tahun 2003-2017. Sejak adanya pergantian kepala desa yang memiliki visi misi yang berbeda dari kepala desa sebelumnya. Salah satu visi misinya ingin memberikan wisata kepada masyarakat sekitar melalui bekas tambang kapur tersebut. Sejak 2018 awal diadakan pembersihan sampah yang melibatkan swadaya masyarakat dan PEMDES, kegiatan pembersihan dilakukan selama 1 tahun. Awal pembangunan pada tahun 2019 dan di tahun 2020 mulai dibuka untuk umum oleh kepala desa Bapak Abdul Halim.

Asal mula dari penamaan wisata Setigi ini berasal dari singkatan Selo, Tirto, dan Giri (Setigi) yang masing masing memiliki arti, Selo berarti batu, Tirto berarti air, dan Giri memiliki arti bukit. Yakni sebuah barisan bukit kapur masif dan panjang berwarna putih. Banyak yang menyebutnya mirip dengan kastil-kastil Yunani. Wisata Setigi ini berada di Jl. Raya Deandles No. 33-88 Desa Sekapuk kecamatan Ujung Pangkah, Gresik. Wisata ini menyajikan keindahan panorama alam perbukitan kapur dengan berbagai bentuk goa dan cerukan yang dihasilkan dari aktivitas penambangan beberapa puluh tahun silam. Panorama tenggelamnya matahari atau sunset turut menambah eksotisme obyek wisata ini. Alam pedesaan dan keramahan masyarakatnya turut menambah daya tarik obyek wisata ini.

Awal mula didirikannya wisata Setigi karena ide dari bapak Abdul Halim

\footnotetext{
${ }^{6}$ Fajar WH, "Desa 'Miliarder' Sekapuk Sabet Juara 1 Desa Brilian,” diakses 28 Juli 2021, https://katadesa.id/index.php/dari-desa-ke-desa-1/284-desa-miliarder-sekapuk-sabet-juara-1desa-brilian.
} 
selaku kepala desa yang baru menjabat saat itu. Untuk perbatasannya sendiri dibagian utara masih pemukiman warga dan tambang kapur, bagian timur merupakan jalan utama desa Sekapuk, lalu bagian barat yang saat ini masih aktif menjadi tambang kapur, dan bagian selatan menjadi pemukiman warga Desa Sekapuk. Wisata Setigi sendiri setiap minggunya hampir 1000 pengunjung dan untuk 1 bulannya kurang lebih 4000 pengunjung.

Sesampai di Wisata Setigi Desa Sekapuk pengunjung akan disuguhi pemandangan berupa hamparan perbukitan kapur nan eksotis. Ditambah dengan suasana khas pegunungan yang sejuk akan membuat siapa saja betah berada di wisata ini. Tempat ini memang memiliki daya tarik tersendiri bagi wisatawan, keindahan bukit kapur tersebut yang bisa dijadikan spot foto instagramble yang akan memanjakan para pengunjung.

Di wisata Setigi memiliki beberapa tempat dan wahana bermain, yaitu tangga drajat yang terdiri dari 99 anak buah tangga, saat berada dipuncak anak tangga akan terlihat jelas wisata segiti dari atas puncak dan juga bekas pahatan dari penambang kapur akan terlihat begitu indah, jembatan putih, untuk wahana anakanak kolam banyu gentong, adapun wahana yang baru launching yakni kolam hijabers dan patung KI begawan segiti.

Kemudian candi topeng nusantara, gerbang gaib, patung semar, goa pancawarna, jembatan peradaban, rumah adat honai, rumah apung, monumen setigi, pahatan nogo puspo. Selain itu ada juga danau buatan dengan jembatannya, wahana wisata air, spot foto, dinding topeng, hingga gunung kapur bekas tambang yang terlihat indah. Pengunjung juga bisa mengelilingi arena wisata menggunakan mobil ATV dan motor trail mini. Tidak hanya itu ada juga Replika masjid dengan arsitektur persia, castil castil bergaya eropa hingga bangunan bangunan bergaya nusantara seperti Candi Topeng Nusantara.

Sementara itu di sebelah selatan dari area wisata ada sebuah gua yang didepatnya terdapat patung semar. Didalam gua tersebut terdapat 10 pitutur (kalimat bijaksana) yang ditulis dalam 3 bahasa yakni Indonesia, Inggris dan Jawa

Dengan pembangunan komplek wisata seluas 5 hektare ini dikatakan baru dikelola separuh atau 75\%, sehingga akan mencoba terus untuk dikembangkan. Mulai dari pembangunan kolam renang, bumi perkemahan, gedung serbaguna, dan tembok penghubung. ${ }^{7}$ Dan ini Wisata Setigi dikelola oleh Bumdes Sekapuk yang dimiliki pemerintah desa dan warga desa setempat, agar tetap terjamin keindahan dan kejujurannya atas transparansi dana yang selalu dilakukan. Jika pengelola bukanlah warga desa sekapuk itu sendiri maka akan terjadi konflik maka dari itu kepala desa tetap ingin pengelola adalah orang dalam alias warga desa sekapuk itu

7 "Uniknya Wisata Setigi di Gresik, Bukit Kapur yang Instagramable Halaman all Kompas.com," diakses 27 Juli 2021, https://travel.kompas.com/read/2020/08/04/200700527/ uniknya-wisata-setigi-di-gresik-bukit-kapur-yang-instagramable?page=all.

Nasirudin Al Ahsani, dkk | 143 
sendiri.

Meskipun Daya Tarik Wisata ini masih tergolong baru dan masih dalam proses pengembangan, namun sudah banyak wisatawan yang berkunjung ke tempat ini. Bahkan obyek ini juga pernah dijadikan sebagai back ground shooting acara Celebrity on Vacation dan beberapa acara stasiun TV lainnya. Hebatnya lagi Daya Tarik Wisata ini telah beberapa kali dikunjungi wisatawan manca Negara termasuk baru-baru ini turis dari Kanada juga berkunjung ke sini. Jika Daya Tarik Wisata ini dikembangkan secara maksimal maka tidak menutup kemungkinan kedepannya akan menjadi sebuah Daya Tarik Wisata atau bahkan Destinasi Wisata unggulan di Kabupaten Gresik maupun di Jawa Timur. ${ }^{8}$ Wisata segiti juga dipilih untuk mewakili Kota Pudak dalam lomba tingkat Nasional yang digelar Kemendagri RI.

\section{Komponen Wisata}

Dalam buku Panduan SKK dan TKK Saka Pariwisata yang diterbitkan oleh Kementerian Kebudayaan dan Pariwisata, setidaknya ada 8 jenis wisata: Yaitu: 1) Wisata alam atau ekowisata Wisata Alam, 2) Wisata ziarah, 3) Wisata budaya, 4) Wisata kesehatan, 5) Wisata pertanian (Agrowisata), 6) Wisata buru, 7) Wisata konvensi, dan 8) Wisata educational tourism (wisata pendidikan). ${ }^{9}$

Wisata setigi masuk dalam kategori wisata alam, yang sudah ada campur tangan manusia. Karena yang awalnya bekas tambang kapur, kini diubah menjadi wisata yang didalamnya banyak terdapat ikon wisata setigi yang dibuat oleh masyarakat disekitar tempat wisata. Seperti dengan adanya danau dan air terjun buatan, beberapa bukit kapur yang sudah digali menjadi kolam dan juga panggung area bermain anak, lalu terdapat ukiran topeng yang ada didinding bukit kapur tersebut. Selain itu terdapat tangga yang sangat panjang yang dapat menghubungkan kita dengan puncak tertinggi bukit kapur,selain itu kita bisa melihat keseluruhan dari berbagai sudut wisata setigi. Karena bekas tambang kapur dan cuaca kota gresik yang sangat panas pengelola wisata telah memberikan beberapa bangunan gazebo yang memang di fasilitasi untuk para pengunjung agar tidak merasa kepanasan dan betah berada didalam tempat wisata setigi tersebut. Mereka para pengelola tidak hanya mementingkan keindahan wisata setigi saja melainkan kenyamanan para pengunjung mulai dari tersebarnya toilet di segala titik yang ada.

Zulkifli menyebutkan komponen tempat wisata meliputi fasilitas-fasilitas yang terlibat dalam penyelenggaran wisata, diantaranya: 1. Sarana transportasi, 2. Sarana akomodasi, 3. Sarana makanan dan minuman, 4. Objek dan atraksi wisata,

\footnotetext{
8 "Selo Tirto Giri (SETIGI) - Disparbud Gresik," diakses 27 Juli 2021, https://disparbud.gresikkab.go.id/2020/10/07/selo-tirto-giri-setigi/.

${ }^{9}$ Panduan SKK dan TKK Saka Pariwisata (Jakarta: Kementerian Kebudayaan dan Pariwisata, 2011).
}

144 | Nasirudin Al Ahsani, dkk 
5. Sarana hiburan, 6. Toko cinderamata, dan 7. Pramuwisata. ${ }^{10}$

Untuk saran transportasi wisatan bisa menyewa mobil ATV ataupun trail mini yang disediakan oleh pengelola untuk mengelilingi wisata setigi. Setelah membayar tiket masuk yang telah ditetapkan, tentunya wisatawan akan dimanjakan juga fasilitas yang telah disediakan. Fasilitas disana sudah cukup memadai, antara lain Area Parkir, Toilet, Mushola, Gazebo, Spot Foto, Area kuliner, dan lainnya. Lengkapnya fasilitas tentunya akan menambah kenyamanan dan kepuasan para wisatawan.

Untuk sarana akomodasi seperti hotel masih dalam tahap perencanaan dan belum terealisasikan. Adapun sarana dan prasarana di wisata Setigi terdapat area parkir sepeda motor dan mobil. Toilet yang ada di beberapa titik, ada juga musholla yang di sediakan agar pengunjung wisata mudah untuk mencari tempat ibadah. Ada juga Area panggung batu yang merupakan area luas tempat bermain anak-anak, juga spot-spot foto, Selain itu Danau yang menjadi maskot dari wisata tersebut, jembatan peradaban, kolam banyu gentong, pemandian hijabers, stand cinderamata dan termasuk pusat Informasi di wisata Setigi.

Lalu terdapat area kuliner yang menyediakan beberapa stand kuliner yang berbeda, stand kuliner tersebut bukan milik pribadi melainkan milik lembaga dan di kelola oleh pusat pengelola wisata Setigi agar para pengunjung tidak di resahkan dengan harga yang melambung tinggi yang tidak sesuai dengan katalog yang ada. Hala tersebut bertujuan agar setiap lembaga desa menjadi lembaga yang mandiri dan mendapatkan uang tambahan agar tidak bergantung dengan uang dari iuran masyarakat.

Ada beberapa stand yang menjual cinderamata, stand tersebut merupakan penjualan dari beberapa RT di Desa Sekapuk. Dan harga cinderamata dari harga 5.000 rupiah sampai sekitar harga 100.000 rupiah. Seperti yang kami lihat untuk pembeli cinderamata sama seperti tempat wisata pada umumnya, para wisatawan membeli cinderamata yang nantinya akan menjadi oleh-oleh khas wisata setigi. Di wisata Setigi memiliki 3 pramuwisata yang di koordinator oleh ibu lis.

Untuk pramuwisatanya sendiri diwajibkan bisa berbicara 2 bahasa, karena di wisata Setigi sebelum pandemi Covid-19 pernah didatangi turis dari 3 negara. Menurut para pengunjung pramuwisata yang ada disana sangat memberikan kesan baik terhadap para pengunjung yang datang ke wisata Setigi, mereka juga tidak lupa menerapkan sistem 3S (Senyum,Sapa, dan Salam), sehingga banyak wisatasan senang berkunjung ke wisata setigi. Selain keramahan dari para karyawan yang membuat para pengunjung betah ialah banyaknya ikon atau tempat-tempat yang tidak akan ditemukan ditempat wisata yang lain. Karena budaya 3S sangat penting diterapkan di era sekarang dimana orang yang mulai cuek dan tidak peduli dengan

${ }^{10}$ Zulkifli, "Pengembangan Kawasan Wisata Dam Bili-Bili Berbasis Masyarakat Di Kecamatan Parangloe Kabupaten Gowa" (skripsi, Makassar, UIN Alauddin, 2017).

Nasirudin Al Ahsani, dkk | 145 
orang lain dan hilangnya budaya senyum,salam,sapa itulah alasan mengapa wisata setigi menerapkan hal ini.

\section{Perencanaan Partisipatif}

Konsep Perencanaan Partisipatif adalah proses perencanaan dan pengambilan keputusan dalam program pembangunan seringkali dilakukan dari atas ke bawah (top down planning). Rencana program pengembangan masyarakat biasanya dibuat di tingkat pusat dan dilaksanakan oleh pemerintah daerah. Masyarakat sering kali diikutkan tanpa diberikan pilihan dan kesempatan untuk memberikan masukan dan peranan. Menurut Rina Wijaya, ciri-ciri perencanaan partisipatif adalah 1) Terfokus pada kepentingan masyarakat, 2) Partisipatoris, 3) Dinamis, 4) Sinergitas, 5) Legalitas, 6) Fisibilitas. ${ }^{11}$

Wisata Setigi ini di bangun karena timbul sebuah masalah, polemik masalah yang timbul selama 13 dekade kepemimpinan sebelum bapak Abdul Halim. Manager wisata tersebut merupakan salah satu bukti dan pelaku sejarah, karena pihak manager dulu pernah menjabat sebagai ketua RT pada tahun 2000-2012. Sumber masalahnya dijadikan tempat pembuangan sampah selama bertahun-tahun pasca tambang dan itu merupakan sebuah polemik bagi RT 05, karena semua sampah dari Desa Sekapuk di buang pada daerah pasca tambang. Saat hujan sampah-sampah tersebut akan mengeluarkan bau busuk, dari situlah muncul ide untuk dijadikan wisata oleh Abdul Halim selaku kepala desa.

Hal ini dilakukan juga sebagai bentuk tanggung jawab kepala desa terhadap potensi yang ada di Desa Sekapuk ini. Pembangunan ini harus ada leadership yang kuat, apabila kita bergantung dari aspirasi masyarakat tidak akan dibangun. Seperti masyarakat di Desa Sekapuk banyak hampir 60 ribu, apabila kita mencari aspirasi ini itu tidak akan terlaksana program kerja ini. Jadi kita harus ada konsep yang kita buat, setelah itu dan itu melibatkan semua elemen stakeholder yang ada di desa. Untuk konsepnya sendiri sudah dimiliki oleh kepala desa. Jadi masyarakatnya mengikuti apa yang sudah dimiliki oleh kepala desa, sebagai bentuk rasa tanggung jawab masyarakat dengan apa yang sudah dipilih dalam pemilihan kepala desa saat itu.

Untuk mensukseskan rencana tersebut, adapun pertemuan rutin yang dilakukan setiap bulan di tanggal 1 yang di hadiri oleh para anggota BUMDES (Badan Usaha Milik Desa), PEMDES (Pemerintahan Desa), lembaga desa lainya seperti (RT \& RW) dan anggota masyarakat lainnya. Untuk rapatnya sendiri dilakukan secara transparan untuk membahas tentang anggaran keuangan, evaluasi, planing kedepannya. Perencanaan dan pelaksanaan tempat wisata memang

\footnotetext{
${ }^{11}$ Rina Wijaya, "Forum pengambilan keputusan dalam proses perencanaan pembangunan di era otonomi daerah: Studi kasus di kelurahan Jebres Kecamatan Jebres Kota Surakarta" (Universitas Gadjah Mada, 2003), http://etd.repository.ugm.ac.id/home/detail_pencarian/10418.
}

146 | Nasirudin Al Ahsani, dkk 
melibatkan semua pihak dari berbagai aspek masyarakat yang ada. Karena masyarakat merasa pembangunan tempat wisata ini sangat menguntungkan bagi kelangsungan hidup masyarakat sekitar. Untuk konsep dari wisata setigi ini hanya mengikuti konsep dari kepala desa namun untuk pengelolaan wisata tersebut melibatkan seluruh masyarakat dari berbagai aspek masyarakat yang ada mulai dari RT/RW, BUMDES, dan lembaga desa lainnya.

Untuk pengelolahannya wisata segiti memperkerjakan masyarakat sekitar dengan syarat wajibnya KK dan KTP Desa Sekapuk sehingga dari itu bisa mengurangi pengangguran yang ada di Desa Sekapuk dan juga meningkatkan perekonomiannya. Untuk stand kulinernya sendiri dikelolah oleh ibu-ibu PKK, sedangkan untuk stand cinderamatnya dikelolah oleh setiap RT yang berada di Desa Sekapuk. Dari apa yang disampaikan oleh Umar Efendi selaku manager, bahwa wisata segiti masih belum $100 \%$ pembangunannya melainkan hanya $75 \%$, karena masih banyak rencana yang belum terealisasikan seperti didatangkannya perahu asli yang masih berfungsi yang nantinya akan digunakan sebagai edukasi dan merealisasikan flaying fox.

Pihak pemerintahan desa berhak melakukan pembangunan apapun tanpa menggunakan dana dari pemerintah. Dana tersebut 100\% dari masyarakat Desa Sekapuk yang diperoleh dari program menabung bersama. Untuk tatanan peraturan yang diatur oleh daerah tidak dianut oleh masyarakat Desa Sekapuk karena dana ini merupakan dana murni dari masyarakat desa dan pihak PEMDES memiliki peraturan sendiri. Untuk tata nilainya sendiri mereka pihak pengelolah melakukan secara transparan terkait masalah dana anggaran desa. Dan setiap bulan pada tanggal 01 selalu dilakukan rapat bersama mulai dari evaluasi dan perhitungan anggaran yang dilakukan secara bersama tanpa adanya rahasia diantara para lembaga desa dan seluruh aspek masyarakat yang ada di desa sekapuk tersebut.

\section{Pengembangan Masyarakat}

Pengembangan masyarakat adalah upaya mengembangkan sebuah kondisi masyarakat secara berkelanjutan dan aktif berlandaskan prinsip-prinsip keadilan sosial dan saling menghargai. Pengembangan masyarakat menerjemahkan nilainilai persamaan, keterbukaan, saling timbal balik, pertanggungjawaban, pilihan, partisipasi, saling menguntungkan, kesempatan, dan pembelajaran terus menerus. ${ }^{12}$

Pertemuan rutin dilakukan di wisata Setigi secara transparan. Mindset kepala desa dalam pengembangan masyarakat agar lebih mandiri seperti RT/RW yang dulunya bergantung pada dana anggaran desa saat ini sudah memiliki dana sendiri. Kedua terkait edukasi untuk menabung pada lembaga desa. Untuk pengembangan masyarakatnya sendiri dengan cara memberikan kesempatan dengan membuka

${ }^{12}$ Zubaedi, Pengembangan Masyarakat: Wacana \& Praktik (Jakarta: Kencana, 2013). 
stand yang dimana standnya sendiri dari kelompok ibu PKK dan tiap RT/RW yang ada di Desa Sekapuk. Pemberdayaan UMKM juga dilakukan dengan pembuatan olahan makanan berupa makanan oleh-oleh khas wisata setigi yang dibuat oleh ibu Inggit dengan bantuan warga sekitar yang dimonitoring oleh ibu PKK. Selain itu, pengembangan masyarakat juga dilakukan dengan cara memperkerjakan masyarakat Desa Sekapuk sebagai karyawan di wisata setigi. Dengan adanya hal tersebut para pekerja ataupun karyawan diwajibkan memiliki Kartu Keluarga ataupun KTP asli penduduk Desa Sekapuk Kecamatan Ujung Pangkah.

Masih menurut Zubaedi, Pengembangan masyarakat adalah komitmen dalam memberdayakan masyarakat lapisan bawah sehingga mereka memiliki berbagai pilihan nyata menyangkut masa depannya. Masyarakat lapisan bawah umumnya terdiri atas orang-orang lemah karena tidak memiliki kemampuan untuk mengontrol sarana produksi. ${ }^{13}$

Dalam hal ini, bentuk pemberdayaan terhadap masyarakat berupa edukasi tentang peluang dalam usaha, selain itu tentang penanam saham untuk wisata setigi yang nantinya dari penanam saham tersebut bisa mendapatkan keuntungan sesuai dengan perjanjian yang telah dibuat dan terakhir terkait umkm yang dimonitoring oleh ibu PKK. Makanan tersebut dapat kita cicipi pada saat weekend dan tanggal merah dengan membayar tiket sebesar 20.000 rupiah. Namun jika weekday kita hanya membayar tiket sebesar 15.000 rupiah tetapi tidak dapat mencicipi makanan khas wisata setigi.

Untuk penghasilan masyarakatnya sendiri mengalami peningkatan dari keuntungan penanaman 1 lembar saham sebesar 2.400.000 rupiah di wisata setigi. Untuk keuntungannya pertahun mencapai 500.000 rupiah dan juga bisa lebih dari itu. Untuk kenaikan pada tiap tahunnya tergantung dari bertambahnya jumlah penanaman saham. Peneliti tidak mendapatkan tabel peningkatan ekonomi Desa Sekapuk pada saat berada di lapangan. Namun mendapatkan data pagu indikatif.

PAGU INDIKATIF TAHUN 2019 >>>>>>>>>>> Rp. 2,039.398.000,-

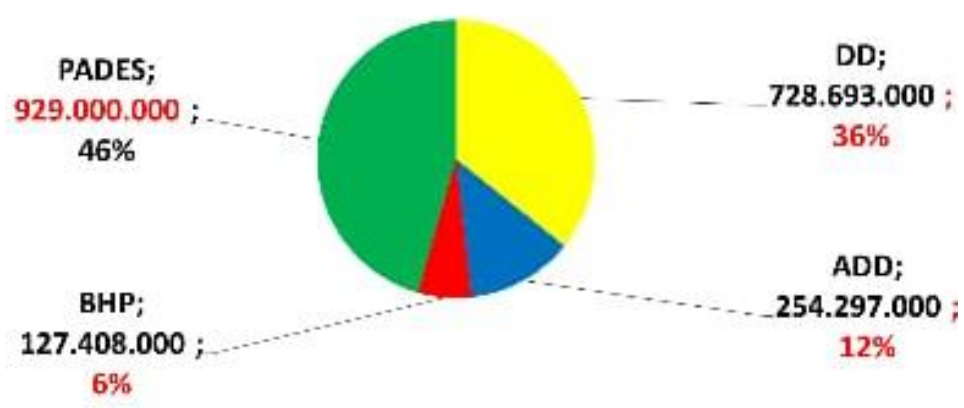

PAGU INDIKATIF DESA SEKAPUK TAHUN 2020 Bp 2,936,843,000

${ }^{13}$ Ibid.

148 | Nasirudin Al

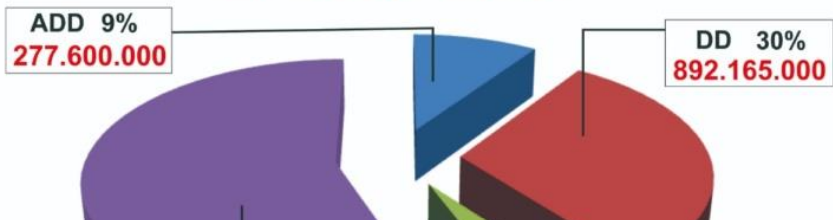


Umar Efendi, manager wisata Setigi mengatakan adanya indeks desa setigi yang awal mulanya desa tertinggal sekitar satu tahun lebih, kemudian berubah menjadi desa yang lebih maju. Setelah bertahun-tahun indeksnya berubah menjadi desa berkembang, kemudian di tahun 2020 menjadi desa mandiri, namun masyarakat desa merasa kurang puas dengan indeks terakhir yang diperoleh. Akhirnya mereka mendeklarasikan sendiri menjadi desa miliarder. Karena terkait pencapaian badan aspirasi desa yang awal mulanya 180 juta sebelum bapak Abdul Halim menjabat, di saat beliau menjabat hasil yang diperoleh mencapai lebih dari 900 juta. Dan saat ini sudah mencapai angka milliar rupiah, untuk target selanjutnya mereka menargetkan sebesar 7 milliar lebih.

\section{Konsepsi Pemberdayaan Masyarakat}

Konsepsi pemberdayaan masyarakat ada 3 komponen yang terdiri atas: 1) Proses yaitu pemberdayaan yang menekankan pada proses struktural kekuatan, atau kemampuan kepada masyarakat, 2) Sekunder yaitu yang menekankan pada proses menstimulasi dalam mendorong masyarakat untuk meningkatkan kemampuan, dan 3) Keberdayaan masyarakat.

Untuk proses wisata setigi berbentuk swadaya karena semua dari masyarakat dan dana dari masyarakat mulai dari pembersihan setiap Jum'at. Untuk pembersihan wilayah Setigi, setiap RW-nya perwilayah, misalnya wilayah 1 Jumat pertama wilayah 2 untuk Jum'at kedua dan seterusnya. PEMDES dan masyarakat terlibat di dalamnya. Untuk dananya sendiri awal mulanya kepala desa memiliki ide untuk mengajak masyarakatnya untuk menabung agar menjadi pengusaha wisata dengan program menabung bersama. Tujuan awalnya berupa pemerataan jadi setiap KK harus memiliki 1 lembar saham sebesar 8.000 rupiah, yang diwujudkan dalam investasi Taplus. Tapi niatan baik itu belum tentu diterima dengan baik apalagi saat itu masa transisi kepala desa. 
Akhirnya dana yang dibutuhkan tidak sesuai dengan tabungan masyarakat yang masuk, setelah itu diubah menjadi masyarakat boleh menabung lebih dari 5 per KK-nya itu pun masih kurang. Data Pemdes Sekapuk, saat ini ada 4.673 warga yang tercakup dalam 1.257 KK (kepala keluarga), yang tersebar di 29 RT dan 5 RW yang ada di Desa Sekapuk. Sehingga kepala desa memutuskan siapa pun yang mau menabung dan percaya dengan program yang telah dibuat oleh kepala desa terkait wisata setigi ini selain masyarakat Desa Sekapuk, diperbolehkan. Jadi terkait pendanaan sudah melakukan berbagai tahapan seperti diatas.

Melalui taplus invest yang dikelola BUMDes, satu lembar saham dihargai Rp 2.400.000 atau dengan skema menambung Rp 8000 per hari atau Rp 200.000 per bulan. Untuk terkait saham tersebut sudah terikat perjanjian dan memiliki aturan, jadi setiap masyarakat akan mendapat hasil yang adil.Wisata Setigi ini ada Musdes (Musyawarah Desa) yang dilaksanakan setiap tanggal 1 yang membahas seperti evaluasi-evaluasi RT, RW, Pamong semua diundang menjadi 1. Nantinya Musdes itu sendiri seperti Pak RT nanti memberikan apa yang didapat dari Musdes akan di beritahukan kepada warganya. Jadi semuanya tertera dan terlihat secara transparan, karena sudah ada lampirannya mulai dari pengeluaran pemasukan semua dari Musdes sudah ada datanya semua.

\section{Bentuk Keterlibatan Masyarakat}

Bentuk keterlibatan masyarakat dalam pariwisata sangat berbeda. Keterlibatan masyarakat dapat berupa: a. Bekerja sebagai karyawan tetap atau paruh waktu, b. Menyediakan pelayanan jasa, c. Mengembangakan pariwisata secara mandiri berbasiskan kemasyarakatan (community based tourism). ${ }^{14}$

Karyawan wisata Setigi sendiri merupakan masyarakat Desa Sekapuk. Untuk masuk menjadi karyawan wisata Setigi itu memang yang pertama wajib pelamar pekerjaan memiliki KTP dan KK Desa Sekapuk. Untuk Karyawannya sendiri memang menjadi karyawan tetap, tetapi kontrak setiap 6 bulan sekali. Bentuk pekerjaan karyawannya di bagian pusat Informasi yang bertugas memberikan terkait pelayanan wisatawan dan mempromosikan wisata setigi, penjaga ikon wisata segiti yang bertugas untuk mengawasi wisatawan dan membantu wisatawan jika ada yang meminta bantuan seperti membantu untuk memotretkan di ikon tersebut, penjaga tiket, bagian kebersihan tempat wisata, korlap yang bertugas untuk melaporkan segala sesuatu yang terjadi di wisata segiti kepada manager wisata setigi, juru parkir, bendahara yang bertugas untuk mengatur keuangan, dan manager. Manager bertugas untuk memimpin, mengarahkan dan mengawasi staf untuk mencapai kesuksesan, dan

14 I Nengah Subadra, "Ekowisata Hutan Mangrove dalam Pembangunan Pariwisata Berkelanjutan: Studi Kasus di Mangrove Information Center, Desa Pemogan, Kecamatan Denpasar Selatan, Kota Denpasar" (Tesis, Denpasar, Universitas Udayana, 2006).

150 | Nasirudin Al Ahsani, dkk 
Di wisata setigi juga terdapat pelayanan jasa pramuwisata yang dikoordinator oleh ibu Iis. Pramuwisata disini ada 3 orang dan diwajibkan bisa berbicara 2 bahasa. Wisata Setigi tidak menyediakan jasa makan, tetapi untuk stand-nya banyak menjual payung, makan dan cinderamata. Untuk mengelilingi area wisata seluas itu, wisatan bisa menyewa mobil ATV ataupun trail mini yang disediakan oleh pengelola untuk mengelilingi wisata Setigi.

Melalui produk 'Dapur Mbok Inggih' yang digawangi PKK Desa Sekapuk, masyarakat membuat jajanan makanan minuman tradisional. Omzetnya pun luar biasa, dan strategi ini mampu meningkatkan perekonomian masyarakat sekitar di tengah pandemi.Sementara itu Ketua Bumdes Sekapuk Asjudi menambahkan, wisata Setigi merupakan satu dari lima unit usaha yang dikembangkan oleh desanya. Empat unit usaha lain, Perusahaan Air Masyarakat (PAM), usaha multi jasa yang melayani simpan pinjam masyarakat, pengolahan sampah masyarakat, serta pengolahan tambang.

Tidak Hanya itu, pihak pengelola Setigi gresik juga mengajak masyarakat untuk membuat jajanan tradisional yang dikemas dengan menarik. Lalu, setiap pengunjung atau wisatawan yang datang diwajibkan untuk membeli satu produk yang orisinal dibuat oleh warga Desa Sekapuk.

\section{Wisata Berbasis Masyarakat}

Menurut Isnaini Mualissin konsep Community Based Tourism memiliki beberapa prinsip-prinsip dasar yang dapat digunakan sebagai Tool Community Development bagi masyarakat setempat yakni : 1. Mengakui, mendukung dan mempromosikan wisata yang dimiliki masyarakat 2. Melibatkan anggota masyarakat sejak awal dalam setiap aspek 3. Mempromosikan kebanggan masyarakat 4. Meningkatkan kualitas hidup masyarakat 5. Memastikan kelestarian lingkungan dan sumber daya alam 6. Membagikan manfaat keuntungan secara adil diantara anggota masyarakat. ${ }^{15}$

Seluruh masyarakat ikut andil dalam menjaga dan merawat tempat wisata setigi untuk promosi para karyawan yang merupakan seluruh masyarakat Desa Sekapuk melakukan kegiatan promosi melalui media cetak dan elektronik seperti brosur dan instagram maupun google. Sejak awal masyarakat ikut andil yang dimulai dari pembersihan sampah yang ada pada bekas tambang kapur yang sekarang ini menjadi tempat wisata setigi yang jauh lebih baik dari beberapa tahun sebelumnya, setelah itu dalam hal dana, pembangunan, pengelolahan, dan juga semua hal yang ada kaitannya dengan tempat wisata setigi ini sendiri.

Wisata setigi semerupakan ikon khas dari Desa Sekapuk hal itu menjadi kebanggaan yang luar biasa untuk masyarakat Desa sekapuk karena dengan adanya

15 Isnaini Muallisin, "Model Pengembangan Pariwisata Berbasis Masyarakat di Kota Yogyakarta," Jurnal Penelitian Bappeda Kota Yogyakarta 2 (2007): 5-15.

Nasirudin Al Ahsani, dkk | 151 
wisata setigi ini menjadikan Desa Sekapuk menjadi desa yang lebih maju lagi dengan indek desa miliader. Untuk kualitas hidup masyarakat sangatlah berbeda dari tahun-tahun sebelumnya dimana 12 tahun yang lalu bekas tambang kapur ini dijadikan tempat pembuangan sampah namun semenjak pergantian kepala desa semuanya berubah dan kemajuan Desa Sekapuk semakin meningkat mulai dari perekonomian masyarakat hingga keberhasilan yang luar biasa atas berdirinya wisata setigi.

Untuk kelestarian lingkungannya warga sekapuk bukan tidak menjaga tapi merubah dan merawatnya jauh lebih baik, karena pada saat itu tempat wisata ini adalah bekas tambang kapur yang sudah tidak beroperasi sejak lama dan dijadikan tempat pembuangan sampah oleh masyarakat dan akhirnya dibersihkan dan dirubah serta dirawat sedemikian rupa. Setiap bulan pada tanggal 01 dilakukan transparansi data mulai dari data keuangan, data pengunjung dan data pengeluaran setiap bulannya, keadilan selalu ditegakkan karena seluruh aspek masyarakat dan para lembaga desa bekerja sama dengan baik tanpa adanya perselisihan paham maulun keuntungan.

Model pendekatan masyarakat (community approach) menjadi standar baku bagi proses pengembangan pariwisata dimana melibatkan masyarakat didalamnya adalah faktor yang sangat penting bagi kesuksesan produk wisata. D'amore dalam Perencanaan Pariwisata Perdesaan Berbasis Masyarakat karya Hadiwijoyo memberikan guidelines model bagi pengembangan pariwisata berbasis masyarakat, yakni : a. Mengidentifikasi prioritas pembangunan yang dilakukan penduduk lokal (resident) b. Mempromosikan dan mendorong penduduk lokal c. Melibatkan penduduk lokal dalam industri atau pengembangan wisata d. Investasi modal lokal atau wirausaha sangat dibutuhkan e. Partisipasi penduduk dalam event-event dan kegiatan yang luas $\mathrm{f}$. Produk wisata untuk menggambarkan identitas lokal. ${ }^{16}$

Pembangunan wisata setigi ini dilakukan untuk memprioritaskan semua masyarakat desa sekapuk agar menjadi desa yang lebih maju dan tidak tertinggal dari segi perekonomian. Pembangunan dilakukan dengan tahap berkala dan tidak terjadi secara instan dan banyak campur tangan masyarakat Desa Sekapuk itu sendiri. Adapun produk lokal yang mereka tawarkan yakni kripik ibu Inggit, keripik ini hasil industri rumahan yang dikelola oleh ibu Inggit itu sendiri dan melalui beberapa tahap hingga keripik itu bisa menjadi produk lokal dari Desa Sekapuk. Saat awal mula visi misi dari kepala desa mulai terealisasikan semua masyarakat desa sekapuk ikut andil mulai dari pembersihan sampah hingga pembangunan wisata setigi sampai sekarang ini.

Untuk hasil dari stand cinderamata dan stand makanan dimasukkan ke dalam kas dan diivestasikan ke wisata setigi, serta penghasilan dari banyaknya pengunjung

16 Suryo Sakti Hadiwijoyo, Perencanaan Pariwisata Perdesaan Berbasis Masyarakat (Yogyakarta: Graha Ilmu, 2012), 72.

152 | Nasirudin Al Ahsani, dkk 
wisata setigi diberikan kepada warga yang menanam saham dan diolah kembali. Hasil pembagiannya bisa diambil kapanpun dan tidak ada bunga tambahan. Semua kegiatan yang ada di wisata setigi berjalan dengan sukses dan selalu dibantu oleh masyrakat sekitar mulai dari lembaga desa hingga seluruh aspek masyarakat yang ada. Cinderamata yang menggambarkan ikon khas dari setigi ialah kaos yang disablon dengan gambar wisata setigi serta keripik ibu Inggit yang menjadi ikon khusus dari wisata setigi ini.

\section{Faktor pendorong dan penghambat}

Suryana menjabarkan tiga faktor penyebab keberhasilan, antara lain: 1) Kemampuan dan kemauan. Orang dengan kemampuan namun tidak memiliki kemauan untuk berwirausaha, serta sebaliknya. Keduanya akan mengalami kesulitan untuk menjadi sukses. 2) Tekad yang kuat dan kerja keras. Orang dengan tekat kuat namun tidak mau bekerja keras, serta orang yang mau bekerja keras namun tidak memiliki tekad. Keduanya tidak akan berhasil. 3) Kesempatan dan peluang. Seorang wirausaha sudah seharusnya mengenali peluang yang ada dan berusaha meraihnya ketika ada kesempatan merupakan salah satu faktor yang menentukan keberhasilan seorang.

Untuk kemampuan dan kemauan dalam menjalankan wisata setigi ini masyarakat dan semua lembaga desa sangat berantusias karena dengan adanya wisata ini dapat meningkatkan perekonomian masyarakat sekitar. Para pengelola wisata melakukan promosi dan menurut opera pengelola tidak ada cara lain selain promosi dalam mengenali peluang di tengah pengunjung wisata. Dan untuk setiap karyawan juga diwajibkan untuk mempromosikan wisata tersebut di sosial media. Lembaga desa dalam menjalankan wisata setigi ini memiliki cara atau teknisnya sendiri, selain dengan cara promosi, mereka juga mewajibkan masyarakat sekitar untuk like di akun media sosial wisata setigi, memberikan pelayanan yang baik kepada wisatawan, memberikan kenyamanan seperti dalam hal menjaga kebersihan yang ada di wisata setigi dan hal-hal yang lain.

Dengan adanya pandemi Covid-19 ini pihak wisata memberikan pelayanan pengecekan suhu badan, memberikan masker kepada wisatan yang tidak menggunakan masker, mengingatkan wisatan tetap selalu menggunakan masker dan juga menyediakan tempat cuci tangan di setiap area. Faktor internal dalam kesuksesan wisata ini dengan adanya antusias warga yang sangat besar, produk olahan yang menjadi makanan khas wisata setigi sehingga dapat dijual, adanya sarana dan prasana yang memadai seperti wahana bermain anak-anak, spot foto dan lain sebagainya. Kalau untuk faktor eksternal berupa faktor alam berupa bekas tambang kapur.

Berkenaan dengan hambatan, pastinya terdapat keterbatasan pengelolaan dalam mengelola daya tarik wisata tersebut. Keterbatasan dibagi menjadi tiga 
macam yaitu : a. Keterbatasan operasional, meliputi administrasi publik, kurangnya koordinasi dan kurangnya informasi. b. Keterbatasan struktural, meliputi sikap profesional, kurangnya keahlian, dominasi kaum elit, kurangnya sistem hukum yang tepat, kurangnya sumber daya manusia yang terlatih, partisipasi masyarakat, kurangnya sumber daya keuangan karena biaya yang relatif tinggi. c. Keterbatasan budaya, meliputi faktor apatis atau rendahnya tingkat kesadaran dalam masyarakat.

Wisata Setigi pernah terjadi keterbatasan dana dalam pembangunan wisata ini karena membutuh dana yang banyak, namun kepala desa memiliki ide dengan cara program menabung bersama. Dan sampai saat ini program itu berjalan dengan lancar. Untuk masalah hambatan dari faktor internal tidak ada, namun untuk dari faktor eksternal sendiri yang awal mula pendapatannya 5 miliar pertahun dan data statistik pengunjung tiap bulannya mancapi 26.000 orang. Namun karena dengan adanya pandemi Covid-19 yang semakin parah, dan aturan pembatasan pemerintah, maka mengalami penurunan hampir 30\%.

Sektor pariwisata turut terdampak kasus virus Corona atau Covid-19. Contohnya di Wisata Setigi. Saat ini, pengunjung Wisata Setigi anjlok. Sebelum ada kasus Covid-19, pengunjung Wisata Setigi bisa mencapai 3.000-4.000 orang per hari. Sekarang hanya ada ada sekitar 100 pengunjung per hari. Sejak pemberlakuan Pembatasan Sosial Berskala Besar (PSBB) yang merupakan kebijakan pemerintah untuk menekan penyebaran Covid-19, wisata di ujung utara Gresik ini juga tutup selama dua bulan. Walaupun demikian wisata setigi ini masih ramai pengunjung dan wisata yang dipercayai oleh masyarakat tentunya dengan tetap mematuhi protokol kesehatan. Tidak hanya itu, pengunjung wajib bermasker. Sebelum masuk area wisata wajib cuci tangan dan dicek suhu badan dengan thermal gun oleh petugas. Di berbagai titik banyak dijumpai petugas yang mengawasi pengunjung agar tak bergerombol. Bahkan, pengelola sengaja menyediakan area berjemur serta menyediakan tempat cuci tangan.

Hambatan sumber daya Sumber daya berguna untuk menangkap segala peluang dan kemungkinan yang ada. Hal ini biasanya berkaitan dengan kemampuan finansial dan bantuan dari orang lain yang dapat menyokong, seperti keluarga, teman, maupun organisasi kelompok. Berikut hambatan yang terjadi pada sumber daya: a) Ketersediaan bahan baku b) Kurang terampil dalam pekerjaan c) Terbatasnya alat d) Keterbatasan infrastruktur e) Dana yang kurang f) Faktor lingkungan

Hambatan yang terjadi berkenaan dengan faktor lingkungan yaitu penanam pohon di area wisata segiti yang cukup lama dan membutuhkan dana yang cukup besar. Karena harus membeli pohon dan tanah merah. Wisata setigi sendiri adalah bekas tambang kapur oleh sebab itu pohon sulit untuk tumbuh, sehingga masyarakat sana membeli tanah merah dan menimbun tanah tersebut agar pohon bisa ditanam dan tumbuh. Karena pada saat awal dibangunnya wisata setigi,wisata 
ini sangat tandus dan gersang dikarenakan seluruh titik dan lahannya terbuat dari kapur untuk mengatasi hambatan sumber daya alam tersebut para pengelola berinisiaftif untuk membuat wisata setigi ini menjadi wisata yang jauh lebih hijau dan lebih rindang lagi. Agar para pengunjung juga tetap dapat merasakan kehijauan dan kesejukan dari wisata setigi meskipun pengelola harus menimbun tanah kapur dengan tanah merah dan membeli banyak tumbuhan dan pepohonan hijau dengan harga yang fantastis atau tidak murah.

\section{Kesimpulan}

Berkenaan dengan komponen wisata, wisatawan akan dimanjakan dengan fasilitas yang telah disediakan. Fasilitas disana sudah cukup memadai, antara lain Area Parkir, Toilet, Mushola, Gazebo, Spot Foto, Area kuliner, dan lainnya. Wisatan juga bisa menyewa mobil ATV ataupun trail mini yang disediakan oleh pengelola untuk mengelilingi wisata setigi, setelah membayar tiket masuk yang telah ditetapkan. Perencanaan wisata dimulai ketika melihat problem sampah selama bertahun-tahun pasca penambangan. Lalu muncul ide dari kepala desa untuk menjadikannya tempat wisata. Untuk mensukseskan rencana tersebut, adapun pertemuan rutin yang dilakukan setiap bulan di tanggal 1 yang di hadiri oleh para anggota BUMDES (Badan Usaha Milik Desa), PEMDES (Pemerintahan Desa), lembaga desa lainya seperti (RT \& RW) dan anggota masyarakat lainnya.

Pengembangan masyarakatnya sendiri dengan cara memberikan kesempatan dengan membuka stand yang dimana standnya sendiri dari kelompok ibu PKK dan tiap RT/RW yang ada di Desa Sekapuk. Pemberdayaan UMKM juga dilakukan dengan pembuatan olahan makanan berupa makanan oleh-oleh khas wisata setigi yang dibuat oleh ibu Inggit dengan bantuan warga sekitar yang dimonitoring oleh ibu PKK.

Faktor pendukung adalah kemampuan dan kemauan dalam menjalankan wisata setigi ini masyarakat dan semua lembaga desa sangat berantusias karena dengan adanya wisata ini dapat meningkatkan perekonomian masyarakat sekitar. Sedangkan faktor penghambatnya Wisata Setigi pernah terjadi keterbatasan dana dalam pembangunan wisata ini karena membutuh dana yang banyak, namun kepala desa memiliki ide dengan cara program menabung bersama. Dan sampai saat ini program itu berjalan dengan lancar. Untuk masalah hambatan dari faktor internal tidak ada, namun untuk dari faktor eksternal sendiri yang awal mula pendapatannya 5 miliar pertahun dan data statistik pengunjung tiap bulannya mancapi 26.000 orang. Namun karena dengan adanya pandemi Covid-19 yang semakin parah, dan aturan pembatasan pemerintah, maka mengalami penurunan hampir $30 \%$.

\section{Daftar Pustaka}

Nasirudin Al Ahsani, dkk | 155 
Hadiwijoyo, Suryo Sakti. Perencanaan Pariwisata Perdesaan Berbasis Masyarakat. Yogyakarta: Graha Ilmu, 2012.

jatimnet.com, dan jatimnet.com. "Bahaya Tumpukan Sampah Plastik di Gresik Mengancam.” Bahaya Tumpukan Sampah Plastik di Gresik Mengancam. Diakses 28 Juli 2021. https://jatimnet.com/bahaya-tumpukan-sampahplastik-di-gresik-mengancam.

Muallisin, Isnaini. "Model Pengembangan Pariwisata Berbasis Masyarakat di Kota Yogyakarta." Jurnal Penelitian Bappeda Kota Yogyakarta 2 (2007): 5-15.

Network, Ayo Media. "Setigi, Wisata Anyar Bekas Batu Kapur dan Tempat Pembuangan Sampah." AyoSurabaya.com. Diakses 28 Juli 2021. https://www.ayosurabaya.com/read/2021/06/15/11964/setigi-wisata-anyarbekas-batu-kapur-dan-tempat-pembuangan-sampah.

Panduan SKK dan TKK Saka Pariwisata. Jakarta: Kementerian Kebudayaan dan Pariwisata, 2011.

"Selo Tirto Giri (SETIGI) - Disparbud Gresik." Diakses 27 Juli 2021. https://disparbud.gresikkab.go.id/2020/10/07/selo-tirto-giri-setigi/.

"SIPSN - Sistem Informasi Pengelolaan Sampah Nasional." Diakses 8 Juli 2021. https://sipsn.menlhk.go.id/sipsn/.

Subadra, I Nengah. "Ekowisata Hutan Mangrove dalam Pembangunan Pariwisata Berkelanjutan: Studi Kasus di Mangrove Information Center, Desa Pemogan, Kecamatan Denpasar Selatan, Kota Denpasar." Tesis, Universitas Udayana, 2006.

Tim Penulis PS. Penanganan dan Pengolahan Sampah. Bogor: Penebar Swadaya, 2008.

"Uniknya Wisata Setigi di Gresik, Bukit Kapur yang Instagramable Halaman all Kompas.com." Diakses 27 Juli 2021. https:/travel.kompas.com/read/ 2020/08/04/200700527/uniknya-wisata-setigi-di-gresik-bukit-kapur-yanginstagramable?page $=$ all.

Utami, Nurwita. "Pengelolaan Sampah Di Negara-Negara Maju." Indonesia Environment \& Energy Center (blog), 8 Juni 2020. https://environmentindonesia.com/pengelolaan-sampah-di-negara-negara-maju/.

WH, Fajar. "Desa 'Miliarder' Sekapuk Sabet Juara 1 Desa Brilian.” Diakses 28 Juli 2021. https://katadesa.id/index.php/dari-desa-ke-desa-1/284-desa-miliardersekapuk-sabet-juara-1-desa-brilian.

Wijaya, Rina. "Forum pengambilan keputusan dalam proses perencanaan pembangunan di era otonomi daerah: Studi kasus di kelurahan Jebres Kecamatan Jebres Kota Surakarta." Universitas Gadjah Mada, 2003. http://etd.repository.ugm.ac.id/home/detail_pencarian/10418.

Zubaedi. Pengembangan Masyarakat: Wacana \& Praktik. Jakarta: Kencana, 2013.

Zulkifli. "Pengembangan Kawasan Wisata Dam Bili-Bili Berbasis Masyarakat Di Kecamatan Parangloe Kabupaten Gowa.” Skripsi, UIN Alauddin, 2017. 